\title{
German minister bemoans weak response
}

Vienna. Angela Merkel, Germany's environment minister, last week attacked a conference on the Chernobyl accident organized by the International Atomic Energy Agency (IAEA) for failing to issue a strong statement on the closing down of the Chernobyl reactor and other similar nuclear reactors, which she argued could have been taken to next week's G-7 meeting on nuclear safety (see opposite)

Instead, the four-day technical conference, which summarized the medical and sociological consequences of the accident, as well as the measures already taken to ensure future reactor safety, drew a relatively mild set of conclusions about whether reactors of the RBMK type such as those at Chernobyl - should be decommissioned.

A joint team of German, French and Russian experts concluded that some fundamental failures in RBMK design have been corrected in many plants, even though important safety deficits, which vary from plant to plant, remain. Moreover, it stated, the lack of understanding of western experts of detailed engineering aspects of RBMK reactors made it difficult to recommend closure of specific plants.

The compromise statement reflects the different interests of the West, which is concerned primarily about the safety of nuclear power in the newly independent states (NIS), and of the countries themselves, which are concerned about its price.

Adolf Birkhofer, head of the German Society for Reactor Safety, who advises the German government on such issues, told the meeting that the complicated design of the 15 operating RBMK reactors created so many potential problems that they should all be shut down as soon as possible. But closure can only be authorized by the states in which they are located, and Lithuania, Ukraine and Russia each maintain that they can continue to operate the reactors securely.

Western European countries now accept

\section{back nuclear research'}

ment has opposed the development of nuclear weapons, and had stopped further tests on Agni.

BJP says it is committed to a nuclear-free world. But it adds that it will continue to develop nuclear weapons if countries that now have atomic bombs do not renounce them. It is opposed to the comprehensive test-ban treaty in its present form, and "will not agree to the fissile material control regime". The party, which currently rules three states, is putting up candidates in all of India's 22 states, and hopes to obtain a majority in the 520-seat lower house of the parliament.

K. S. Jayaraman that their wish for serious discussion about closure of the 15 plants will not take place at next week's G-7 meeting, and are concentrating their efforts of the complete closure of Chernobyl, where two reactors continue to operate.

Last December, the G-7 countries signed a memorandum of understanding in which they pledged ECU2 billion (US $\$ 2.5$ billion) to help support the closure of the remaining two reactors, the completion of alternative

\section{IMAGE UNAVAILABLE FOR COPYRIGHT REASONS}

Human cost? Children in the leukaemia ward for the victims of Chernobyl, at Kiev children's hospital.

electricity generating plants, and strengthening of the so-called sarcophagus, the containment structure that was built over the destroyed reactor, which is feared to be unstable.

Since then, behind-the-scenes negotiations have raised this figure to ECU3.1 billion, with Ukrainian environment minister Yuri Kostenko holding out for more. Kostenko is also negotiating over how much of the sum now on the table would be in the form of loans, and how much in straight aid.

Even if an agreement over Chernobyl is reached, it is unlikely to come into force until 2000 at the earliest, and it would be several more years before the reactors were actually switched off. Total decontamination of the area around Chernobyl is estimated to require at least 15 years to complete.

Merkel, who chaired the IAEA conference, stressed the importance of the closures

$\approx$ if public faith in nuclear power is to be restored. "If we want to [justify] use of nuclear energy, the safety of nuclear power plants has to be given absolute priority," she said.

The conference further concluded that the medical consequences of the Chernobyl accident were quite different 을 from original predictions. An unexpectedly high increase in thyroid cancers in young children has been reported. But there is there is as yet no evidence of an increase in leukaemias among so-called 'liquidators', those who were exposed to high levels of radiation when working in the heavily contaminated zones after the accident.

Similarly there is as yet no firm scientific evidence for an increase in other solid tumours that can be ascribed to the accident. But stress - a consequence of the prevailing fear that the health, and therefore future, of individuals have been irreversibly harmed - was generally acknowledged to be one of the most debilitating consequences of the accident. Alison Abbott

\section{African continent goes 'nuclear-free'}

Cape Town. African countries last week signed a treaty declaring a desire to keep the continent free of nuclear weapons. At a ceremony in Cairo, 50 of Africa's 53 nations signed the Treaty of Pelindaba, banning the possession, testing or storing of nuclear arms.

Ironically, the treaty is named after the site occupied by the South African Atomic Energy Corporation near Pretoria, where it was concluded. This is where the only known weapons-grade uranium was produced on the continent, used in the late 1980s to manufacture South Africa's six nuclear devices, which have subsequently been dismantled.

The treaty, which seeks to promote the use of nuclear science for peaceful processes, creates the world's third nuclear-free zone, following similar pacts by Latin American and South Pacific countries. Madagascar, Somalia and the Seychelles did not sign the treaty for "political or technical" reasons, accord- ing to the Eygptian foreign ministry.

The United States, France, Britain and China were also present to sign an annexe to the pact promising not to use or threaten to use nuclear weapons against any African country. The fifth nuclear power, Russia, balked at signing, citing the presence of a US military base on the Indian Ocean island of Diego Garcia, considered African territory under the treaty.

The treaty will be monitored by the African Commission on Nuclear Energy (Afcone), which is expected to employ a small permanent staff whose work will be overseen by 12 commissioners. South Africa has offered to host Afcone, and this offer has been taken up by the Organisation of African Unity.

In addition to South Africa, a key role was played in the negotiations by the government of Egypt, which already faces a possible nuclear threat in the Middle East from Israel. Michael Cherry 